\title{
Pemekatan Keratinase dari Bacillus sp. 24 untuk Meningkatkan Aktivitas Dehairing
}

\author{
Suharti, Arinta Agni Dewantari, dan Nurlaili Lisdiyarini \\ Jurusan Kimia, FMIPA \\ Universitas Negeri Malang \\ suharti.fmipa@um.ac.id
}

\begin{abstract}
Abstrak
Keratinase dapat diproduksi oleh Bacillus sp MD24 dengan menggunakan bulu ayam sebagai substrat. Ekstrak kasar keratinase tersebut terbukti dapat digunakan sebagai agen dehairing. Namun demikian, proses dehairing memerlukan waktu 72 jam karena rendahnya aktivitas keratinase. Penelitian ini bertujuan meningkatkan kemampuan keratinase sebagai agen dehairing. Dua hal telah dilakukan dalam upaya meningkatkan aktivitas ekstrak kasar enzim yaitu peningkatan produksi enzim dan pemekatan enzim. Usaha untuk meningkatkan produksi enzim dilakukan dengan suplementasi media menggunakan sumber karbon tambahan berupa gula sederhana (sukrosa, glukosa, atau fruktosa). Peningkatan konsentrasi enzim dengan cara pemekatan dilakukan melalui pengendapan enzim menggunakan amonium sulfat dengan tingkat kejenuhan $80 \%$. Enzim hasil pengendapan diuji kemampuannya dalam dehairing kulit kambing pada berbagai waktu inkubasi. Penelitian menunjukkan bahwa suplementasi media dengan karbon sederhana memberikan hasil yang kontradiksi dimana penambahan sukrosa, glukosa, atau fruktosa justru menurunkan produksi ekstrak kasar keratinase. Sedangkan pemekatan mampu meningkatkan aktvitas enzim dari $8,79 \mathrm{U} / \mathrm{mL}$ sebesar $20,3 \mathrm{U} / \mathrm{mL}$ dan mampu menghilangkan bulu dengan waktu perendaman selama 48 jam.
\end{abstract}

Kata-kata kunci: Bacillus, keratinase, gula sederhana, pemekatan

\begin{abstract}
Keratinase can be produced by Bacillus sp MD24 under chicken feathers as a substrate. The crude extract keratinase is proven to be used as a dehairing agent. However, dehairing process takes $72 h$ because of the low activity of keratinase. This study aims to improve the ability of keratinase as dehairing agents. Two things have been done in an effort to increase the activity of the crude extract, increasing production of enzymes and enzyme pre-concentration. Efforts to increase enzyme production were done by supplementing the media using additional carbon sources using simple carbohydrates (sucrose, glucose, or fructose). Enzyme pre-concentration was done by enzyme precipitation using ammonium sulphate at $80 \%$ saturation level. The precipitated enzyme was tested for its ability to dehair the goat skin at various incubation times. Supplementation of the medium with simple carbohydrate showed contradictory results where the addition of sucrose, glucose, or fructose actually decreased the production of keratinase. As expected, the pre-concentration increased the activity of the enzyme from 8.3 $\mathrm{U} / \mathrm{mL}$ of $20.3 \mathrm{U} / \mathrm{mL}$ and the concentrated enzyme is capable to remove the goat hairs with immersion time for 48 hours.
\end{abstract}

Keywords: dehairing, keratinase, simple carbohydrate, pre-concentration

\section{PENDAHULUAN}

Industri penyamakan kulit di Indonesia telah mengalami sejarah panjang dan pertumbuhan yang pesat untuk memproduksi bahan-bahan berbahan kulit. Bahan baku industri ini berbasis kepada sumber daya alam dalam negeri, sehingga mampu memberikan nilai tambah yang cukup tinggi. Hal ini didukung dengan semakin meningkatnya pasokan bahan baku seiring dengan meningkatnya produksi ternak. Contohnya jumlah populasi ternak kambing di Jawa Timur dari tahun ke tahun mengalami peningkatan rata-rata sebesar 3,32\% per tahun (Disnak Jatim, 2016). Hasil samping industri pemotongan hewan yang berupa kulit diolah menjadi barang-barang kulit, seperti: tas, sarung tangan, garmen, dan lain-lain. Pengolahan kulit yang dikenal dengan penyamakan kulit mampu mengubah kulit mentah menjadi kulit yang lebih stabil, tidak mudah membusuk, dan cocok 
untuk beragam kegunaan (Mustakim, dkk., 2010). Meskipun pengolahan kulit memberikan kontribusi besar bagi perekonomian secara global, namun juga menimbulkan pencemaran bagi lingkungan. Limbah-limbah dari industri pengolahan kulit dapat mengubah sistem di lingkungan dan menjadi media transmitan bagi berbagai penyakit (Arunachalam, dkk., 2009). Secara garis besar proses penyamakan kulit terdiri dari tiga tahap, yaitu: pra-penyamakan, penyamakan, dan pasca penyamakan. Pada tahap pra-penyamakan, kulit terlebih dahulu melalui proses dehairing (buang rambut) dengan merendamnya dalam kapur $\left(\mathrm{Ca}(\mathrm{OH})_{2}\right)$ dan sulfida $\left(\mathrm{Na}_{2} \mathrm{~S}\right)$ yang menghasilkan limbah berupa gas $\mathrm{H}_{2} \mathrm{~S}$ (hidrogen sulfida), bubur rambut, dan lumpur kapur (Jaouadi, dkk., 2009). Gas $\mathrm{H}_{2} \mathrm{~S}$ merupakan gas yang berbahaya bagi kesehatan.

Salah satu metode alternatif yang dapat digunakan untuk mengurangi dampak pencemaran lingkungan dalam proses dehairing yaitu pemanfaatan teknologi enzim dalam proses penyamakan kulit. Menurut Kandasamy, dkk. (2012), protease spesifik yang disebut keratinase dapat diaplikasikan pada proses dehairing kulit kambing. Bulu dan rambut merupakan protein fibrous yang kaya akan sulfur. Struktur keratin kaya akan ikatan disulfida yang membedakan sifat keratin dari protein pada umumnya. Enzim-enzim protase seperti tripsin, pepsin, dan papain tidak mampu mendegradasi keratin. Keratin hanya dapat didegradasi oleh enzim protease spesifik yaitu keratinase karena kemampunnya dalam memutuskan ikatan peptida dan disulfida yang terdapat pada keratin (Gupta \& Ramnani, 2006). Riesmi (2015) telah berhasil mengisolasi bakteri indigenous (Bacillus sp. MD24) dari tanah yang mampu menghasilkan enzim keratinase. Bakteri Isolat Bacillus sp. MD24 dapat mendegradasi bulu ayam yang diamati selama 10 hari dengan \%weight loss sebesar 71,01\%.

Penelitian lebih lanjut tentang keratinase dari Bacillus sp. MD24 telah dilakukan antara uji potensi ekstrak kasar keratinase sebagai agen dehairing (Zuhriyah, 2016). Hasil uji coba menunjukkan bahwa keratinase tersebut dapat digunakan sebagai agen dehairing, namun masih memerlukan waktu yang lama (72 jam). Hal ini kurang menguntungkan bagi industri penyamakan kulit. Lamanya waktu dehairing kemungkinan dapat disebabkan oleh rendahnya aktivitas ekstrak kasar keratinase. Peningkatan aktivitas enzim dalam proses dehairing kulit kambing telah diupayakan dengan dua cara yaitu peningkatan produksi dan pemekatan enzim. Peningkatan produksi enzim dilakukan dengan optimasi pertumbuhan sel salah satunya dengan mencari media yang lebih baik yang mampu menghasilkan biomassa (jumlah sel) yang tinggi dan mampu menghasilkan metabolit yang diinginkan dalam konsentrasi yang tinggi. Sumber karbon digunakan sebagai sumber nutrisi tambahan non protein yang digunakam sebagai sumber energi kimia untuk meningkatkan biomassa, sedangkan pemekatan umumnya dilakukan menggunakan garam atau pelarut organik. Hasil studi terdahulu menunjukkan amonium sulfat pada tingkat kejenuhan antara 60-80\% dapat diaplikasikan untuk pemurnian enzim protease alkali dari Bacillus brevis (Mahariyanti, 2015). Tulisan ini melaporkan hasil upaya peningkatan aktifitas keratinase dari Bacillus sp. MD24 dan kemampuanya dalam mempercepat proses dehairing.

\section{METODE}

\section{Persiapan Media}

Media yang digunakan terdiri dari dua jenis yaitu media NA (nutrient agar) dan media keratin. Media NA padat digunakan untuk peremajaan sel dan media NA cair digunakan untuk pembuatan starter. Sedangkan media keratin digunakan mengklarifikasi kemampuan mikroba untuk mendegradasi keratn dan produksi enzim. Media keratin padat terdiri dari; $0,03 \% \mathrm{~K}_{2} \mathrm{HPO}_{4} ; 0,04 \%$ $\mathrm{KH}_{2} \mathrm{PO}_{4} ; 0,05 \% \mathrm{NaCl} ; 0,01 \% \mathrm{MgCl}_{2} .6 \mathrm{H}_{2} \mathrm{O}$; dan $1,5 \%$ agar dan $0,5 \%$ keratin bubuk, sedangkan media keratin cair untuk produksi digunakan 0,1 $\%$ bulu ayam utuh dan agar dihilangkan dari komponen media. Gula sederhana berupa sukrosa, glukosa dan atau fruktosa ditambahkan ke dalam media produksi untuk melihat pengaruh gula tersebut terhadap produksi enzim.

\section{Peremajaan Biakan Murni Bacillus sp. MD}

Peremajaan biakan murni bakteri Bacillus sp. dilakukan secara aseptik. Media NA padat digunakan secara rutin untuk penyimpanan biakan sedangkan media keratin padat digunakan untuk meyakinkan biakan yang disimpan memang mampu menghasilkan keratinase ekstraselular. Inokulum diinokulasikan pada suhu $37^{\circ} \mathrm{C}$ selama 24 jam.

\section{Produksi Ekstrak Kasar Keratinase Bacillus sp. MD24}

Starter disiapkan dengan cara mengambil 2 ose biakan murni bakteri yang telah diremajakan dan diinokulasikan dalam $10 \mathrm{~mL}$ media cair Nutrient 
Broth (NB). Selanjutnya, inokulum cair tersebut diinkubasi pada suhu $37^{\circ} \mathrm{C}$ diiringi aerasi pada kecepatan $100 \mathrm{rpm}$ selama 18 jam. Selanjutnya, starter diinokulasikan ke dalam $100 \mathrm{~mL}$ media produksi dan diinkubasi pada suhu $37^{\circ} \mathrm{C}$ diiringi aerasi pada kecepatan $100 \mathrm{rpm}$ selama 48 jam. Enzim ekstrak kasar dan bula ayam yang belum terdegradasi dipisahkan secara filtrasi menggunakan kertas saring Whatman 40. Kertas saring yang berisi sisa bulu ayam dikeringkan dan diukur massanya untuk perhitungan persentase massa bulu yang hilang (Weight Loss). Filtrat hasil penyaringan dipisahkan dari sel dengan cara sentrifugasi dingin selama 15 menit dengan kecepatan $10.000 \mathrm{rpm}$ pada suhu $4^{\circ} \mathrm{C}$. Supernatan selanjutnya diperlakukan sebagai ekstrak kasar enzim.

\section{Uji Aktivitas Keratinase Bacillus sp. MD24}

Uji aktifitas dilakukan sesuai prosedur yang dikembangkan oleh Suharti, dkk. (artikel sudah disubmit). Sebanyak $5 \mathrm{~mL}$ keratin $1 \%$ yang telah dilarutkan dalam $50 \mathrm{mM}$ buffer tris- $\mathrm{HCl} \mathrm{pH} 8$ dimasukkan dalam tabung reaksi. Selanjutnya, 1 $\mathrm{mL}$ enzim keratinase ditambahkan pada tabung reaksi tersebut, yang kemudian divortex dan diinkubasi pada suhu $37^{\circ} \mathrm{C}$ selama 30 menit. Setelah itu, aktivitas enzim dihentikan dengan menambahkan $2 \mathrm{~mL}$ TCA $10 \%$ dan sebanyak 1 $\mathrm{mL}$ buffer tris-HCl $50 \mathrm{mM}$ ditambahkan ke dalam campuran. Campuran divortex dan diinkubasi pada suhu $4^{\circ} \mathrm{C}$ selama 30 menit dan disentrifugasi pada $10.000 \mathrm{rpm}$ selama 10 menit. Supernatan hasil sentrifugasi ditentukan kadar tirosinnya dengan mengukur absorbansinya pada panjang gelombang $280 \mathrm{~nm}$. Kontrol reaksi enzimatis diisi larutan dengan komposisi sama, hanya saja tahapan penambahan enzim keratinase diganti dengan buffer tris- $\mathrm{HCl} 50 \mathrm{mM}$, serta pada tahapan penambahan buffer tris- $\mathrm{HCl} 50 \mathrm{mM}$ diganti penambahan enzim keratinase. Absorbansi tirosin sampel dikurangi dengan absorbansi tirosin pada kontrol untuk mengetahui absorbansi tirosin yang dibebaskan selama degradasi keratin oleh keratinase.

\section{Pemekatan Ekstrak Kasar Keratinase dengan Ammonium sulfat 80\%}

Ekstrak kasar keratinase diendapkan dengan penambahan garam ammonium sulfat sedikit demi sedikit sampai dengan tingkat kejenuhan $80 \%$ sambil diaduk perlahan. Penambahan dilakukan pada temperature $4^{\circ} \mathrm{C}$. Campuran selanjutnya disimpan selama 24 jam untuk mengoptimalkan proses pengendapan. Protein yang mengendap dipisahkan dengan sentrifugasi pada suhu $4^{\circ} \mathrm{C}$ selama 20 menit dengan kecepatan $8000 \mathrm{rpm}$. Endapan yang dihasilkan dilarutkan kembali dalam $20 \mathrm{~mL}$ buffer $50 \mathrm{mM}$ Tris- $\mathrm{HCl} \mathrm{pH}$ 8,0 yang mengandung $1 \mathrm{mM}$. Logam $\mathrm{Ca}$ adalah logam yang mampu menginduksi aktifitas keratinase dari Bacillus sp MD24 (Zuhriyah, 2016). Larutan enzim tersebut kemudian didialisis menggunakan membran selofan melawan $50 \mathrm{mM}$ buffer Tris$\mathrm{HCl}$ yang mengandung $1 \mathrm{mM} \mathrm{CaCl}_{2}$ pada suhu $4^{\circ} \mathrm{C}$. Pergantian buffer dilakukan setiap 3 jam selama 12 jam.

\section{Uji Dehairing Kulit Kambing}

Kulit kambing direndam dalam larutan enzim dan diinkubasi pada suhu $37^{\circ} \mathrm{C}$. Setiap 24 jam sekali, kulit kambing dihilangkan bulunya dengan cara menggosoknya menggunakan spatula. Sebagai kontrol, kulit kambing direndam dalam larutan buffer yang digunakan untuk melarutkan enzim.

\section{HASIL DAN PEMBAHASAN}

\section{Regenerasi Biakan Murni Bakteri Bacillus sp. MD24}

Isolat bakteri yang digunakan pada penelitian ini merupakan biakan murni yang sebelumnya telah diisolasi dalam media keratin-agar yang diteliti oleh Riesmi (2015). Regenerasi Bacillus sp. dari kultur murni MD24 merupakan tahap awal untuk mendapatkan bakteri yang sehat dan produktif. Regenerasi isolat bakteri dilakukan pada media padat Nutrient Agar (NA) dan media keratin. Gambar 1 menunjukkan koloni Bacillus sp pada media keratin padat. Setelah beradaptasi dengan media tumbuhnya, perkembangbiakan Bacillus sp. MD24 dapat mudah diamati dengan beberapa ciri-ciri yang jelas, terutama mengenai bentuk, warna, kerapatan (density), dan pengelompokkan koloni-koloni.

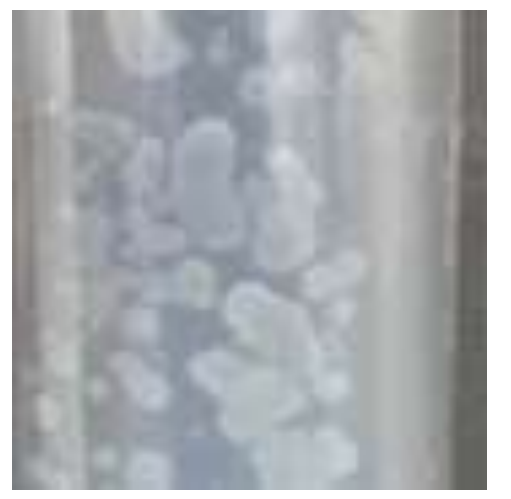

Gambar 1. Koloni Bacillus sp. MD24 dalam Media Keratin 


\section{Produksi Ekstrak Kasar Keratinase Bakteri Bacillus sp. MD24}

Pada tahap ini, sel bakteri melalui fase adaptasi yang lebih panjang karena tidak dilakukan adaptasi menggunakan media produksi (pembuatan starter). Penelitian Hidayati (2016) menunjukkan bahwa terjadi peningkatan aktivitas keratinase Bacillus sp. MD24 dari hari ke-1 hingga ke-3, dimana aktivitas tertinggi diperoleh pada hari ke-3. Dalam penelitian ini enzim ekstrak kasar yang diperoleh pada hari ke-3 memiliki aktivitas keratinase sebesar $8,61 \mathrm{U} / \mathrm{mL}$ dengan persentase Weight Loss yaitu 43,4. Nilai aktivitas keratinase tersebut tidak berbeda jauh dengan hasil yang diperoleh Hidayati (2016) yaitu sebesar 9,97 $\mathrm{U} / \mathrm{mL}$.

\section{Pengaruh Konsentrasi Sumber Karbon terhadap Produksi Keratinase}

Ketika isolat Bacillus sp. MD24 ditumbuhkan pada media bulu ayam, maka bakteri akan memperoleh nutrisi yang berbeda dan lebih sedikit dibanding dalam media NA dan NB. Dalam proses pertumbuhan bakteri Bacillus sp. MD24 di dalam media produksi, bakteri memperoleh beberapa nutrisi makronutrien dan sedikit mikronutrien. Makronutrien karbon dan nitrogen diperoleh dari substrat bulu ayam, $\mathrm{K}^{+}$dari $\mathrm{K}_{2} \mathrm{HPO}_{4}, \mathrm{Mg}^{2+}$ dari $\mathrm{MgSO}_{4}$, sedangkan mikronutrien $\mathrm{Na}^{+}$dari $\mathrm{NaCl}$. Pada tahap ini, Bacillus sp. MD24 juga melakukan aktivitas metabolisme dan menghasilkan enzim keratinase. Isolat bakteri hanya memperoleh nutrisi dari bulu ayam sehingga memaksanya melakukan proses ekskresi keratinase dari dalam sel untuk memecah keratin dan memanfaatkan sumber karbon untuk proses pertumbuhan.

Pada penelitian ini dipelajari pengaruh penambahan sumber karbon yang berupa karbohidrat sederhana yang diharapkan dapat digunakan sel sebagai sumber energi untuk meningkatkan kecepatan pertumbuhan. Sumber karbon yang digunakan bersama dengan bulu ayam adalah sukrosa, glukosa, dan fruktosa. Sedangkan media yang berisi bulu ayam (tanpa penambahan sumber karbon) digunakan sebagai pembanding. Aktivitas keratinase tertinggi pada media produksi yang hanya mengandung bulu ayam saja, sebesar $8,607 \mathrm{U} / \mathrm{mL}$ dan nilai persentase weight loss 43,38\%, kemudian diikuti sukrosa $0,5 \%$ yang memiliki aktivitas enzim 5,62 $\mathrm{U} / \mathrm{mL}$ dan weight loss $28,90 \%$. Seperti dalam penelitian Hidayati (2016) menunjukkan bahwa Bacillus sp. MD24 memiliki aktivitas optimum pada media produksi yang berisi bulu ayam saja, dengan aktivitas enzim ekstrak kasar keratinase yaitu 9,97 U/mL. Terkait konsentrasi sumber karbon, sukrosa $1 \%$, glukosa $1 \%$, dan fruktosa $1 \%$ menunjukkan penurunan aktivitas keratinase jika dibandingkan dengan sumber karbon yang sama dengan konsentrasi $0,5 \%$ (Tabel 1). Sedangkan peningkatan aktivitas keratinase berdasarkan penambahan sumber karbon berturut-turut dari yang paling rendah ke tinggi yaitu: fruktosa, glukosa, sukrosa, kemudian bulu ayam tanpa penambahan karbon. Hasil ini tidak sesuai dengan harapan.

Penurunan aktivitas mungkin dikarenakan jumlah keratinase yang semakin terbatas (Ghose dan Ray, 2010). Pada kondisi dimana hanya bulu ayam yang digunakan sebagai sumber karbon dan nitrogen, sel membutuhkan asam amino yang diperoleh melalui degradasi keratin pada bulu ayam oleh keratinase yang dilepaskannya untuk dua hal yaitu sumber energi dan materi penyusun struktur sel. Apabila karbohidrat sederhana seperti glukosa dan fruktosa tersedia dalam medium bersama dengan bulu ayam, maka glukosa dan fruktosa akan lebih mudah diserap oleh sel dibandingkan protein keratin. Sel akan lebih menghemat energy dengan menggunakan gula dibandingkan memproduksi keratinase untuk memperoleh asam amino sebagai sumber energy. Hal ini berakibat pada penurunan produksi enzim keratinase oleh sel bakteri. Meskipun demikian, keratin masih tetap dibutuhkan oleh sel sebagai sumber asam amin khusunya untuk bahan dasar sintesis protein. Hipotesis ini perlu ditunjang dengan data jumlah sel. Pada penelitian ini tidak dilakukan penghitungan jumlah. Apabila hipotesis ini benar, kemungkinan produksi keratinase akan meningkat kembali apabila glukosa dan fruktosa setelah habis dalam medium produksi. Sedangkan sukrosa yang merupakan disakarida (D-glukosa dan D-fruktosa) bersifat lebih kompleks dan membutuhkan enzim invertase (disebut juga sucrase atau saccharose) untuk menghidrolisisnya menjadi monosakarida. Mengingat sel bakteri membutuhkan energi, maka sel lebih cenderung untuk memproduksi keratinase agar aktivitas metabolismenya tetap berjalan. Sehingga aktivitas keratinase terbilang lebih tinggi pada penambahan sumber sukrosa dibandingkan dengan glukosa dan fruktosa. Namun, hal tersebut perlu dipastikan lebih lanjut dengan pengukuran aktivitas enzim invertase. Penelitian lebih lanjut perlu dilakukan untuk melihat pengaruh karbohidrat kompleks terhadap pertumbuhan. 
Terkait dengan variasi konsentrasi, keratinase pada medium yang ditambahkan sukrosa 0,5\% memiliki aktivitas lebih tinggi dibandingkan sukrosa $1 \%$, demikian pula pada glukosa dan fruktosa. Hal ini menunjukkan semakin kecil konsentrasi penambahan sumber karbon, maka semakin tinggi produksi keratinase. Hasil ini sejalan dengan penelitian Syam (2008) yang menunjukkan bahwa aktivitas enzim selulase tertinggi terdapat pada media dengan konsentrasi selulosa $1 \%$ dengan nilai aktivitas enzim sebesar $0,029 \mathrm{U} / \mathrm{mL}$ jika dibandingkan dengan konsentrasi selulosa sebesar $2 \%$ dan $3 \%$.

Berdasarkan hasil penelitian terkait pengaruh konsentrasi substrat terhadap produksi keratinase, media produksi bulu ayam dan sukrosa $0,5 \%$ memiliki aktivitas yang lebih tinggi dibandingkan penambahan sumber karbon yang lain. Hal ini perlu juga diketahui waktu optimum produksi keratinase untuk mengetahui waktu terbaik melakukan inkubasi media produksi keratinase.

Persentase bulu ayam terdegradasi tertinggi pada media produksi berisi bulu ayam yang diinkubasi hingga hari ke-5 yaitu 61,8. Demikian halnya dengan media produksi yang berisi bulu ayam dan sumber karbon sukrosa $0,5 \%$, yang mengalami peningkatan pada hari ke-5 yaitu 58,8. Hal ini ternyata berbeda dengan uji aktivitas keratinase tertinggi media berisi bulu ayam saja pada hari ke-3. Persentase Weight Loss media bulu ayam tertinggi pada hari ke-5 yaitu sebesar 61,8 dengan aktivitas keratinase $5,05 \mathrm{U} / \mathrm{mL}$. Sedangkan Weight Loss pada hari ke-3 yaitu 42,4 dengan aktivitas keratinase yaitu $8,61 \mathrm{U} / \mathrm{mL}$. Hal ini mengindikasikan bahwa untuk mengamati produksi keratinase maka parameter yang tepat melalui nilai uji aktivitas keratinase, bukan nilai uji Weight Loss. Selain itu, diperlukan penelitian lebih lanjut terkait waktu inkubasi dalam rentang waktu yang lebih lama.

\section{Pengaruh Waktu Penyimpanan terhadap Aktivitas}

Aktivitas enzim dapat menurun selama penyimpanan atau selama pemakaian. Kedua substrat tersebut perlu dipertahankan aktivitas enzimnya agar dapat dipergunakan dalam rentang waktu yang lama. Proses penyimpanan keratinase dilakukan dalam lemari pendingin pada suhu $4^{\circ} \mathrm{C}$. Temperatur ini dipilih untuk keperluan industry untuk menghindari denaturasi akibat proses Freezing and Thawing. Telah lama diketahui bahwa suhu rendah lebih baik daripada suhu tinggi untuk penyimpanan enzim. Hasil uji aktivitas keratinase pada beberapa variasi waktu penyimpanan $(0,24,48$, dan 72 jam $)$ dapat dilihat pada Tabel 2.

Media produksi keratinase pada waktu penyimpanan pada 24,48 , dan 72 jam mengalami penurunan aktivitas keratinase. Hal ini menunjukkan bahwa proses penyimpanan dapat mempengaruhi kerja enzim yang disebabkan oleh 2 hal, yaitu: denaturasi dan autokatalis. Pada suhu sekitar $1-4^{\circ} \mathrm{C}$, penyimpanan dapat menahan kecepatan reaksi kimia dan enzimatis, termasuk pertumbuhan dan metabolisme bakteri. Proses penyimpanan dalam suhu rendah juga dapat mengakibatkan terdenaturasinya protein keratinase, artinya terputusnya sejumlah ikatan air dan berkurangnya kadar protein yang dapat diekstraksi dengan larutan garam. Selain itu, semakin lama penyimpanan, semakin banyak pula keratinase yang dapat mengalami kerusakan karena terjadinya proses autokatalis. Keratinase yang ada mengkatalisis reaksi hidrolisis protein keratinase yang lain. Oleh karena itu, jumlah enzim akan semakin sedikit dan aktivitas keratinase turut mengalami penurunan.

\section{Penentuan Kemampuan Ekstrak Kasar Keratinase Bacillus sp. MD24 sebagai Agen Dehairing Kulit Kambing}

Penentuan kemampuan ekstrak kasar keratinase Bacillus sp. MD24 dalam proses dehairing dilakukan dengan cara merendam kulit kambing ukuran $2 \times 2 \mathrm{~cm}$ yang dikeringkan tanpa bahan kimia dalam larutan ekstrak kasar keratinase selama 0, 24, 48, dan 72 jam. Sebelumnya, ekstrak kasar keratinase ditambahkan kation logam divalen yaitu ion $\mathrm{Ca}^{2+} 1 \mathrm{mM}$ yang mampu meningkatkan aktivitas ekstrak kasar keratinase (Zuhriyah, 2016), dengan kondisi optimum produksi keratinase isolat Bacillus sp. MD24 pada temperatur $37^{\circ} \mathrm{C}$ dan $\mathrm{pH} 8$ (Purwati, 2015). Pengamatan dilakukan secara langsung dengan membandingkan kulit kambing sebelum dan sesudah mengalami reaksi enzimatis. Dari hasil penelitian menunjukkan bahwa ekstrak kasar keratinase Bacillus sp. MD24 memiliki kemampuan dehairing (buang rambut) pada kulit kambing yang dibuktikan dengan proses perendamannya menggunakan ekstrak kasar keratinase dengan waktu perendaman selama 72 jam (Tabel 3). Aktivitas keratinase dalam tahap ini yaitu $8,15 \mathrm{U} / \mathrm{mL}$ dengan persentase Weight Loss sebesar $42 \%$. Proses pemekatan keratinase perlu dilakukan untuk memperoleh hasil yang lebih baik. Ekstrak kasar keratinase telah menunjukkan kemampuannya dalam proses dehairing kulit 
kambing, namun perlu dilakukan pemekatan agar memperoleh waktu perendaman yang lebih singkat. Pemekatan ekstrak kasar keratinase dapat dilakukan dengan metode pengendapan amonium sulfat untuk mengendapkan protein atau enzim yang diinginkan.

Enzim keratinase yang telah terendapkan oleh amonium sulfat didialisis selama 12 jam dengan 4 kali pergantian buffer. Tahap awal dialisis yaitu aktivasi membran selofan untuk menahan protein yang dimiliki oleh isolat Bacillus sp. MD24. Dialisis dilakukan dengan tujuan untuk menghilangkan garam amonium sulfat serta pengotor yang masih ada pada larutan. Penggantian buffer setiap 3 jam sekali perlu dilakukan untuk mencegah kesetimbangan ion antara larutan yang berada di dalam membran

Tabel 1. Persentase Penurunan Aktivitas Keratinase terhadap Variasi Konsentrasi Penambahan Berbagai Jenis Sumber Karbon

\begin{tabular}{ll}
\hline Jenis Sumber Karbon & $\begin{array}{l}\text { Penurunan Aktivitas } \\
\text { Keratinase (\%) }\end{array}$ \\
\hline Bulu ayam saja & 0 \\
Sukrosa 0,5\% & 34,7 \\
Sukrosa 1\% & 64,4 \\
Glukosa 0,5\% & 54,4 \\
Glukosa 1\% & 66,9 \\
Fruktosa 0,5\% & 73,3 \\
Fruktosa 1\% & 93,1 \\
\hline
\end{tabular}

selofan dengan larutan buffer (Dewantari, 2014). Setelah melalui tahap dialisis, larutan enzim keratinase diuji aktivitas enzimnya dan digunakan sebagai agen dehairing kulit kambing.

Aktivitas enzim sebelumnya yaitu $8,79 \mathrm{U} / \mathrm{mL}$ dan setelah pemekatan mengalami kenaikan sebesar 20,3 U/mL. Kenaikan aktivitas enzim keratinase juga mempengaruhi kemampuannya dalam dehairing kulit kambing. Pada perendaman selama 48 jam, sebagian besar rambut telah terlepas dari permukaan kulit kambing. Hal ini menunjukkan apabila larutan enzim keratinase dipekatkan, maka aktivitas enzim dapat mengalami kenaikan dan proses dehairing kulit kambing menjadi lebih cepat 24 jam dari sebelumnya.

Tabel 2. Persentase Keratinase Sisa terhadap Waktu Penyimpanan

\begin{tabular}{lll}
\hline $\begin{array}{c}\text { Jenis Sumber } \\
\text { Karbon }\end{array}$ & $\begin{array}{c}\text { Waktu } \\
\text { Penyimpanan } \\
\text { (jam) }\end{array}$ & $\begin{array}{c}\text { Persentase Sisa } \\
\text { Aktivitas } \\
\text { Keratinase (\%) }\end{array}$ \\
\hline Bulu ayam (tanpa & 0 & 100 \\
penambahan sumber & 24 & 71,6 \\
C) & 78 & 54,9 \\
\hline & 72 & 20,2 \\
Bulu ayam + Sukrosa & 0 & 100 \\
$0,5 \%$ & 48 & 80,6 \\
& 72 & 74,1 \\
\hline
\end{tabular}

Tabel 3. Dehairing Kulit Kambing Menggunakan Ekstrak Kasar Keratinase (0-72 jam)

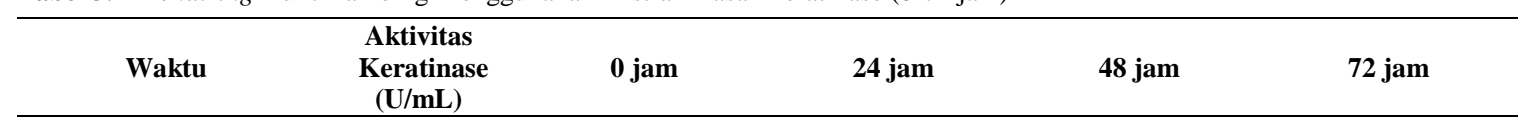

Tanpa Dehairing $\quad 0 \quad 0$

$\begin{aligned} & \text { Dehairing secara } \\ & \text { enzimatis }\end{aligned}$
8,15

Hasil Dehairing
Setelah Pemekatan




\section{KESIMPULAN}

Usaha meningkatkan aktifitas keratinase telah dilakukan melalui dua cara yaitu optimasi produksi dan pemekatan enzim. Optimasi produksi melalui penambahan gula sederhana justru menurunkan produksi ekstrak kasar keratinase. Karbohidrat sederhana tersebut mungkin lebih cepat diserap dan digunakan sebagai sumber energi dibandingkan bulu ayam sehingga sel menurunkan produksi karatinasenya untuk efisiensi. Penambahan karbohidrat kompleks mungkin perlu dicoba pada berbagai perbandingan dengan bulu ayam untuk mengoptimalkan produksi keratinase. Perbandingan massa induser keratin dan karbohidrat kompleks yang terbaik

\section{DAFTAR RUJUKAN}

Arunachalam, C. \& Saritha, K. 2009. Protease Enzyme: an Eco-Friendly Alternative for Leather Industry. Indian Journal of Science and Technology, 2(12), 29-32.

Choirani, G. 2017. Pemurnian Enzim Keratinase Bacillus sp. MD24 Menggunakan Metode Fraksionasi Amonium sulfat. Skripsi tidak diterbitkan. Malang: FMIPA Universitas Negeri Malang.

Data Statistik Populasi Ternak Kab/Kota di Jawa Timur. Dinas Peternakan Provinsi Jawa Timur. (http://disnak.jatimprov.go.id), diakses 10 Agustus 2017.

Dewantari, A. 2014. Efektivitas Amilase Termostabil Isolat Cangar Relatif Terhadap Amilase Komersial dalam Menghidrolisis Amilum dari Tapioka, Maizena, dan Tepung Talas dalam Menghasilkan Glukosa. Skripsi tidak diterbitkan. Malang: FMIPA Universitas Negeri Malang.

Ghosh, B \& Ray, R. 2010. Saccharification of Raw Native Starches by Extracellular Isoamylase of Rhyzopus Oryzae. Biotechnology, 9(2), P 224-228.

Gumilar, J. 2016. Isolasi dan Identifikasi Bakteri serta Produksi Enzim Keratinase sebagai Agensia Buang Rambut Ramah Lingkungan pada Proses Penyamakan Kulit Domba Garut. Disertasi tidak diterbitkan. Yogyakarta: Fakultas Perternakan Universitas Gadjah Mada. akan mampu mendorong pertumbuhan sel dan produksi keratinase. Usaha pemekatan melalui pemekatan menggunakan amonium sulfat $80 \%$ mampu menghilangkan bulu pada kulit kambing pada waktu perendaman yang lebih pendek. Penelitian lebih lanjut perlu dilakukan untuk mengetahui rasio enzim dan luas kulit terbaik untuk keuntungkan industri yang optimum.

Penyimpanan enzim pada temperature $4^{\circ} \mathrm{C}$ menurunkan aktivitas secara linear, sehingga perlu dilakukan usaha untuk mempertahankan stabilitas enzim selama waktu penyimpanan. Liofilisasi terhadap enzim perlu diuji untuk penyimpanan enzim yang lebih efisien untuk diaplikasikan dalam industri.

Gupta, R. \& Ramnani, P. 2006. Microbial Keratinases and Their Prospective Applications: an Overview. Appl Microbial Biotechnol, 70, 21-33.

Hidayati, Arina. 2016. Optimasi Produksi Keratinase dari Bakteri Keratinolitik Bacillus licheniformis MD24. Skripsitidak diterbitkan. Malang: FMIPA Universitas Negeri Malang.

Jaouadi, B., Chaabouni, S. E., Ali, M. B., Messaoud, E. B., Naili, B., Dhouib, A. \& Bejar, S. 2009. Excellent Laundry Detergent Compatibility and High Dehairing Ability of the Bacillus pumilus CBS Alkaline Proteinase (SAPB). Biotechnology and Bioprocess Engineering, 14, 503-512.

Mahariyanti, A. 2015. Optimasi Pemurnian Enzim Protease Alkali Bacillus brevis Menggunakan Metode Fraksinasi Amonium sulfat. Skripsi tidak diterbitkan. Malang: FMIPA Universitas Negeri Malang.

Mustakim, Aris, S., \& Kurniawan. 2010. Perbedaan Kualitas Kulit Kambing Peranakan Etawa (PE) dan Peranakan Boor (PB) yang Disamak Krom. Jurnal Ternak Tropika, 11(1), 38-50.

Riesmi, M. 2015. Isolasi dan Identifikasi Bakteri Indigenous Penghasil Keratinase dari Sampel Tanah. Skripsi tidak diterbitkan. Malang: FMIPA Universitas Negeri Malang.

Syam, K. 2008. Optimasi Produksi dan Aktivitas Enzim Selulase dari Mikrob Selulolitik Asal Rayap. Skripsi tidak diterbitkan. Bogor: FMIPA Institut Pertanian Bogor. 
Zuhriyah, F. 2016. Optimasi Aktivitas Ekstrak Kasar Keratinase dari Bacillus sp. sebagai Agen Dehairing Kulit Kambing. Skripsi tidak diterbitkan. Malang: FMIPA Universitas Negeri Malang. 